The Relationship between the Perception of Distributed Leadership in Secondary Schools and Teachers' and Teacher Leaders' Job Satisfaction and Organizational Commitment H. Hulpia ${ }^{a *}$, Prof. Dr. G. Devos ${ }^{b}$ and Prof. Dr. Y. Rosseel ${ }^{c}$

${ }^{a}$ Department of Educational Studies, Ghent University, Ghent, Belgium

${ }^{b}$ Department of Educational Studies, Ghent University, Ghent, Belgium, and Vrije Universiteit Brussel, Belgium

${ }^{c}$ Department of Data-analysis, Ghent University, Ghent, Belgium

* Corresponding author: Hester Hulpia. Email: Hester.Hulpia@UGent.be 


\title{
The Relationship between the Perception of Distributed Leadership in Secondary Schools and Teachers' and Teacher Leaders' Job Satisfaction and Organizational Commitment
}

\begin{abstract}
This study investigates the relation between distributed leadership, the cohesion of the leadership team, participative decision-making, context variables, and the organizational commitment and job satisfaction of teachers and teacher leaders. A questionnaire was administered to teachers and teacher leaders $(n=1770)$ from 46 large secondary schools. Multiple regression analyses and path analyses revealed that the study variables explained significant variance in organizational commitment. The degree of explained variance for job satisfaction was considerably lower compared to organizational commitment. Most striking was that the cohesion of the leadership team and the amount of leadership support was strongly related to organizational commitment, and indirectly to job satisfaction. Decentralization of leadership functions was weakly related to organizational commitment and job satisfaction.
\end{abstract}

Keywords: distributed leadership; quantitative research; secondary education; job satisfaction; organizational commitment

Article type: research article 


\section{Introduction}

The organizational commitment and job satisfaction of teachers is critical to school effectiveness and school improvement (Firestone \& Pennell, 1993; Rosenholtz, 1989). Previous research has indicated that organizational commitment and job satisfaction are negatively related with staff turnover and absenteeism, and positively related with job effort and job performance (Dee, Henkin, \& Singleton, 2006; Kushman, 1992; Ostroff, 1992). Several studies showed that school leadership is related to teachers' organizational commitment (Hoy, Tarter, \& Bliss, 1990; Koh, Steers, \& Terborg, 1995; Nguni, Sleegers, \& Denessen, 2006) and job satisfaction (Aelterman, Engels, Van Petegem, \& Verhaeghe, 2007; Bogler, 2001, 2005; Evans \& Johnson, 1990). These studies adopted a person-centered approach in which leadership is a quality that exists in one person, the school leader, and examined the effect that this one person has on organizational commitment and job satisfaction. In the past decade, however, these 'single person' leadership models have been left in favour of shared leadership models, which stress the distribution of leadership among the school team (Bush \& Glover, 2003; Goleman, 2002; Gronn, 2002; Leithwood \& Riehl, 2003). Especially in large schools leadership should be distributed across a number of individuals, because principals can no longer develop their leadership through daily interactions with all school members (Firestone, 1996; Firestone \& Martinez, 2007). However, the relation between distributed leadership and the organizational commitment or job satisfaction of teachers and teacher leaders remains unexplored.

The purpose of this study is to gain insight into the perceptions of teachers and teacher leaders on distributed leadership, participative decision-making, and the collaboration of the leadership team in large secondary schools. These perceptions will be examined in relation to the organizational commitment and job satisfaction of teachers and teacher leaders.

\section{Theoretical background}

\subsection{Distributed leadership}


While distributed leadership is a hot topic in the educational management literature, it remains an unclear and divergent concept, lacking a coherent conceptual base (Harris, 2005; Spillane, 2006). In order to operationalize distributed leadership for our study, we distinguish between (a) the formal distribution of leadership functions, (b) the cohesive leadership team, and (c) the participation of teachers.

\section{Definition of formal distributed leadership}

In distributed leadership, various leadership functions are distributed to multiple individuals acting as leaders. These leaders can have formal or informal leadership positions (Spillane, 2006). According to Leithwood and Jantzi (2000) schools benefit most from leadership of a small number of easily identified sources. Similarly, Steinbach (1996) stated that the notion of distributed leadership among senior and middle management levels in schools is widely promoted as a factor contributing to school effectiveness and school improvement. Therefore, we focus on the distribution of leadership functions among the leadership team, consisting of individuals in formal leadership positions in large secondary schools (i.e., the principal, assistant principals, and teacher leaders).

To study formal distributed leadership, we conceptualize leadership in terms of organizational functions and examine which members of the school perform these functions. This is in line with previous research (Camburn, Rowan, \& Taylor, 2003; Heller \& Firestone, 1995; Leithwood et al., 2007; Pounder, Ogawa, \& Adams, 1995). In the present study we concentrate on two core practices of successful leaders, borrowed from the instructional and transformational leadership models (Hallinger, 2003; Leithwood \& Jantzi, 1999): support and supervision.

- Support. Transformational leadership models focus on the leader's role in setting and promoting a collective school vision, as well as motivating and stimulating members of an organization (Bass, 1985; Burns, 1978). We interpret these roles as constituting 
supportive leadership. This leadership function is considered to be easily distributed by the principal to other members of the school team (Barnett \& McCormick, 2003; Bush \& Glover, 2003; Eden, 2001; Heller \& Firestone, 1995; Locke, 2003; Smith \& Piele, 1997).

- Supervision. The supervision of teachers is a leadership function concerned with instructional leadership and focuses predominantly on the role of the principal in directing, controlling, and monitoring (Bamburg \& Andrews, 1990; Hallinger \& Murphy, 1985). This supervisory leadership function is mainly regarded as a function of formally designated leaders and is more difficult to distribute (Eden, 2001; Goldstein, 2003; Spillane, 2006).

The formal distribution of the supportive and supervisory leadership functions is broader than a delegation of tasks. Delegation of tasks refers to the reallocation of work from one person to another, and the person who is delegated a certain task is authorized to carry it out independently (Rayner \& Gunter, 2005). In distributed leadership, however, various functions are stretched over the leadership team; all members pool their expertise and work collaboratively in an interactive way, so that the leadership functions become an emergent property of a group (Gronn, 2002).

Cohesive leadership team and participative decision-making: concepts related to distributed leadership

As stated above, distributed leadership is more than a delegation of tasks and collaboration between interacting individuals is of central importance. In this study we attempt to capture this 'concerted action' by focusing on the cohesion of the leadership team. In order to work in collaboration, the formal leaders should have a coherent management framework, characterized by group cohesion (Bennett, Wise, Woods, \& Harvey, 2003; McGarvey \& Marriott, 1997). This refers to the openness of the team members, their mutual trust, 
communication, and cooperation (Holtz, 2004). The roles of the leadership team members should be unambiguous, known and accepted by all team members and teachers (Barry, 1991; Chrispeels, Castillo, \& Brown, 2000; Grubb \& Flessa, 2006; Leithwood, Jantzi, \& Steinbach, 1999; Muijs \& Harris, 2007; Murphy, 2005). Furthermore, a consensus on the school goals and the school vision should be reached (Bennett et al., 2003; Briggs \& Wohlstetter, 2003; Macbeath, 2005; Mayrowetz, Murphy, Louis, \& Smylie, 2007; Oduro, 2004). These characteristics of the leadership team are crucial in the development of effective distributed leadership (Harris \& Muijs, 2005; Spillane, Diamond, \& Jita, 2003).

By conceptualizing distributed leadership as the formal distribution of leadership among the leadership team, we have not yet included the informal contribution of all school team members in the decision-making process of the school. Leadership can be enacted by the entire educational community (Elmore, 2000; Lashway, 2003) and school leaders should provide leadership while operating under a participative and collaborative arrangement that actively seeks to involve various individuals from the school community in the decision-making process (Copland, 2001). Therefore, apart from the formal distribution of leadership in schools, it is important to take into account the informal distribution of leadership among the whole school team, i.e., the participation of all teachers in school decision-making.

\subsection{Organizational commitment and job satisfaction}

\section{Definition of organizational commitment and job satisfaction}

Organizational commitment and job satisfaction are critical factors in the functioning and success of every organization. Higher levels of organizational commitment and job satisfaction result in more effort and an increased dedication to attain organizational goals, which is closely related to organizational effectiveness (Dee et al., 2006). In this study we define organizational commitment as the relative strength of an individual's identification with, and involvement in a particular organization (Mowday, Steers, \& Porter, 1979). Job satisfaction 
is defined as a pleasurable or positive emotional state resulting from the appraisal of one's job and job experience (Locke, 1976).

The relation between distributed leadership and organizational commitment and job satisfaction

Formal distribution of leadership functions. Empirical research on the impact of distributed leadership on organizational commitment or job satisfaction is lacking. However, numerous benefits associated with distributed leadership have been reported. For example, distributed leadership is expected to foster creativity and innovation (Scribner, Sawyer, Myers, \& Watson, 2004) and to create a higher commitment to the collective vision of the school, with greater sustainability of effort and ownership (Harris \& Muijs, 2003; Morrison, 2002; Neuman \& Simmons, 2000). Furthermore, a positive correlation has been found between distributed leadership and teachers' self-efficacy and level of morale (Harris, 2005). Distributed leadership is also recognized as an essential component of high performance learning organizations (Chrispeels \& Yep, 2004). We expect these benefits to be positively related to teachers' and teacher leaders' organizational commitment and job satisfaction.

However, apart from these advantages, certain disadvantages have been reported. Harris (2005) pointed out that it would be naïve to ignore the major structural, cultural, and micropolitical barriers operating in schools that make distributed forms of leadership difficult to implement. In the traditional hierarchy of leadership in schools, power is expected to stay at the top of the school and the formal hierarchical structure remains a crucial element (Mayrowetz et al., 2007). Research has indicated that the renegotiation of institutional roles can make many people uncomfortable (Copland, 2003; Macbeath, 2005; Neuman \& Simmons, 2000). It can also lead to role conflict and confusion over who has the right to make final decisions. Renegotiating an individual's role can make the line of authority unclear, and can be confusing for administrators and teachers alike (Liontos \& Lashway, 1997; Oswald, 1997; Smith \& Piele, 
1997; Smylie \& Brownlee-Conyers, 1992). For example, some teachers describe leaders distributing leadership functions, as neglecting their leadership responsibilities (Boardman, 2001). Timperley (2005) stated that the distribution of leadership across several people may simply result in the distribution of incompetence. Distributed leadership can also create an increased workload and stress for all school members (Liontos \& Lashway, 1997). The abovementioned disadvantages can obviously have a negative impact on organizational commitment and job satisfaction. In this study we aim to investigate whether the benefits and pitfalls of distributed leadership influence the organizational commitment and job satisfaction of teachers and teacher leaders.

Cohesive leadership team. As mentioned above, a cohesive leadership team is an important precondition for successful distributed leadership. We define a cohesive leadership team as a collaborative and coherent team characterized by clear roles and a consensus among its members regarding the goals of the team. Many studies have shown that group cohesion among employees has a positive influence on organizational commitment and job satisfaction (Wech, Mossholder, Steel, \& Bennett, 1998). Mathieu (1991), for example, stated that cohesive groups can provide emotional support for individuals and is a direct source of satisfaction. Moreover, role clarity has been shown to have a positive association with the employee's commitment and satisfaction (Mathieu \& Zajac, 1990; Tao, Takagi, Ishida, \& Masuda, 1998): commitment and satisfaction are likely to be higher among employees who are sure about what is expected of them. Likewise, a shared vision and consensus among the group members regarding the school goals, especially those that are congruent with the goals of the employees, is assumed to have a positive impact on the commitment and satisfaction of employees (Meyer \& Allen, 1997). However, most of the research concerning group cohesion, role clarity, and goal consensus is situated at the individual level of the group members. Research into teachers' and teacher leaders' perceptions of a cohesive leadership team and the association between these 
perceptions and the organizational commitment and job satisfaction is scarce. The present study will examine whether teachers' and teacher leaders' perceptions of the leadership team is related to their organizational commitment and job satisfaction.

Participative decision-making. Participation in school decision-making is assumed to have a positive impact on the commitment to the school and job satisfaction (Bogler, 2001; Byrne, 1999; French \& Caplan, 1972; Kushman, 1992; Maeroff, 1988). In contrast, Nir (2002) reported that participation in school-based management brings positive effects on commitment to the teaching profession, but yields negative effects on the commitment to the school. Also other authors have concluded that organizational commitment is not directly associated with participative decision-making (Bogler \& Somech, 2004; Louis, 1998; Somech, 2005). Moreover, participation in decision-making does not always occur as a significant predictor of job satisfaction (Taylor \& Tashakkori, 1995).

The relation between context variables and organizational commitment and job satisfaction

Research has indicated that organizational commitment and job satisfaction are influenced by demographic and school variables. In this study, we include context variables which are linked to school leadership: the school size, the size of the leadership team, the principal's level of experience, and the teachers' level of experience. Although many researchers have assumed that context variables influence organizational commitment and job satisfaction (Vandenberghe \& Huberman, 1999), other researchers have suggested that the influence of context variables diminishes when perceptions of the respondents on school leadership are included in predictive models (Bogler, 2005; Culver, Wolfle, \& Cross, 1990). Given these inconsistent views, we include context variables in our analyses and explore whether they are related to the organizational commitment and job satisfaction of teachers and teacher leaders. 
The organizational commitment and job satisfaction of teacher leaders

Next to the above-mentioned variables, the extra role behaviour of the teacher leaders can have an influence on their organizational commitment and job satisfaction. In the present study we examine large Flemish secondary schools, where teacher leaders perform their 'leadership' assignments on a full-time or part-time basis. In contrast to middle managers occupying formal management positions, teacher leaders have responsibility, but no formal authority over other teachers (Harris \& Muijs, 2005). Teacher leaders perform a more fluid and often temporary role in helping to redesign schools, mentor their colleagues, engage in problem solving at the school level, and provide professional growth activities for colleagues (Wasley, 1991). In Flanders, teacher leaders can have different roles and functions. In some schools teacher leaders are coordinators who perform a coordinating role for the first (i.e., 12-14-yearold pupils), second (i.e., 14-16-year-old pupils), or third stage (i.e., 16-18-year-old pupils) of secondary education. Other schools opt for teacher leaders who are responsible for the support of pupils (student counsellors), the support of teachers (mentors), or the organizational and administrative aspects of technical and vocational schools (technical advisors). Flemish secondary schools do not have middle managers with formal authority over other teachers.

Teacher leaders frequently report the feeling that they are the 'meat in the sandwich', because they are neither part of the senior management team nor are they solely teachers. They play a dual role and may feel caught in the crossfire between the expectations of different levels in the school hierarchy (Bennett, Newton, Wise, Woods, \& Economou, 2003). Smylie (1999), for example, stated that some teacher leaders believe that their leadership roles conflict with their classroom teaching or create tension with their colleagues. Such work related experiences can lead to stress. Teacher leadership roles may also be ambiguous and foster uncertainty regarding responsibility or how a role should be performed. Furthermore, the extra workload can have a negative impact on the job satisfaction of these individuals (Kilcher, 1992; Smylie, 
1999). On the other hand, the extended role and empowerment of teacher leaders can lead to greater commitment to the school and to job satisfaction (Rinehart \& Short, 1994; Somech \& Drach-Zahavy, 2000).

The relation between organizational commitment and job satisfaction

Research has consistently shown a positive relation between organizational commitment and job satisfaction (Mathieu, 1991). However, the direction of this relation is inconclusive. Some researchers have claimed that organizational commitment influences job satisfaction (Culver, Wolfle, \& Cross, 1990; Vandenbergh \& Lance, 1992). These researchers have argued that employees adjust their satisfaction levels to be consistent with their current commitment levels. This position is consistent with a social psychological perspective that assumes individuals develop attitudes consistent with situations to which they are already committed (Currivan, 1999). In contrast, other researchers have assumed that organizational commitment is influenced by job satisfaction (Fresko, Kfir, \& Nasser, 1997; Nguni et al., 2006; Reyes \& Shin, 1995). Researchers taking this position have assumed that the employee's orientation toward a specific job necessarily precedes his/her orientation towards the entire organization (Currivan, 1999). Other studies have concluded that there is a reciprocal relation between job satisfaction and organizational commitment (Farkas \& Tetrick, 1989). Further research has suggested that there is no significant causal relation between commitment and satisfaction, due to their common causes (Currivan, 1999). As the direction of this relation has not been firmly established, the present study investigates the relationship between organizational commitment and job satisfaction.

\section{Research design}

\subsection{Purpose}


The purpose of this study is threefold. First, this study aims to gain insight into the perceptions of teachers and teacher leaders on formal distributed leadership, the cohesion of the leadership team, participative decision-making, and teachers' and teacher leaders' job satisfaction and organizational commitment. Second, we analyze the relation between context variables, the amount and formal distribution of the supportive and supervisory leadership function, cohesion of the leadership team, participative decision-making, and the organizational commitment and job satisfaction of teachers and teacher leaders. Third, we investigate the reciprocal relation between organizational commitment and job satisfaction. With these aims outlined, the following research questions will be examined:

1. How do teachers and teacher leaders perceive the amount and distribution of leadership functions among the leadership team, the cohesive leadership team, the participative decision-making, and their organizational commitment and job satisfaction?

2. a. What is the relation between the perceptions of teachers and teacher leaders on distributed leadership and the related concepts (i.e., cohesive leadership team and participative decision-making), and their organizational commitment?

b. What is the relation between the perceptions of teachers and teacher leaders on distributed leadership and the related concepts (i.e., cohesive leadership team and participative decision-making), and their job satisfaction?

3. a. What is the relation between demographic and school variables and the organizational commitment of teachers and teacher leaders?

b. What is the relation between demographic and school variables and the job satisfaction of teachers and teacher leaders?

4. What is the relation between organizational commitment and job satisfaction of teachers and teacher leaders?

The research questions are presented in Figure 1. 


\section{<< INSERT FIGURE 1 AROUND HERE >>}

\subsection{Research instrument}

A major challenge is the quantitative assessment of distributed leadership. A quantitative instrument investigating the distribution of supportive and supervisory leadership functions among formal leadership positions is not available. To tackle this problem, we developed the Distributed Leadership Inventory (DLI; Hulpia, Devos, \& Rosseel, in press). This questionnaire was developed on the basis of the theoretical framework used in this study. The DLI measures the distribution of leadership functions. Next, the cohesion of the leadership team, participative decision-making, and the organizational commitment and job satisfaction are investigated. Demographic variables (e.g., years of job experience, age, and gender) and school variables (e.g., school size) are integrated in the questionnaire. A final version of the instrument is presented in Appendix.

\section{Measurement of the amount and the formal distribution of the leadership functions}

In the first part of the questionnaire, respondents are asked to rate the individual leadership functions of the principal, the assistant principals, and the teacher leaders. For each subgroup the items are rated on a five-point Likert scale ranging from 0 (never) to 4 (always). The scales used in this first part of the DLI were selected on grounds of demonstrated validity and reliability in previous research. For the supportive leadership function we used: strength of vision (De Maeyer, Rymenans, Van Petegem, van den Bergh, \& Rijlaarsdam, 2007), supportive behavior (Hoy \& Tarter, 1997), providing instructional support, and providing intellectual stimulation (Leithwood \& Jantzi, 1999). The supervision scale was developed based on instructional leadership theory concerning supervising and monitoring teachers (Blase \& Blase, 2002; Hallinger, 2003; Southworth, 2002). 
Although the DLI is mainly based on research instruments that were tested for validity and reliability by their authors, the factorial structure was retested. We wanted to avoid any theoretical overlap that may result from using different scales in one instrument. Moreover, the validity of the instruments should be retested as the original research instruments focus on the leadership of only one person, namely the principal. In contrast, the DLI focuses on the leadership functions performed by three subgroups of the leadership team (i.e., the principal, the assistant principals, and teacher leaders). In order to validate the DLI we first conducted exploratory factor analyses on the results of a first stratified randomly selected subsample $(\mathrm{n}=$ 951). Principal axis factoring with promax rotation was adopted in SPSS, since no orthogonality across components was assumed. In order to extract the number of latent factors parallel analyses in R were employed (Horn, 1965). Second, confirmatory factor analysis using AMOS was conducted on the data of the second stratified randomly selected subsample $(n=$ 951) to examine the stability of the exploratory factor structure [principal: $\chi^{2}=353.840(d f=$ 64; $p<.000), \mathrm{CFI}=0.960, \mathrm{TLI}=0.952, \mathrm{SRMR}=0.042, \mathrm{RMSEA}=0.069 ;$ assistant principals: $\chi^{2}=361.794(d f=64 ; p<.000), \mathrm{CFI}=0.957, \mathrm{TLI}=0.948, \mathrm{SRMR}=0.047, \mathrm{RMSEA}=0.070 ;$ and the teacher leaders: $\chi^{2}=390.001(d f=64 ; p<.000)$, CFI $=0.943$, TLI $=0.931$, SRMR $=$ 0.044 , RMSEA $=0.073]$. Lastly, the reliability of the final version of the questionnaire was determined. The cronbach's alpha reliability varies from 0.91 for support of teacher leaders to 0.93 for support of principals and assistant principals. The cronbach's alpha reliability for supervision has a range from 0.79 (teacher leaders) over 0.83 (principal) to 0.85 (assistant principals) (cf. Hulpia et al., in press).

In order to receive a more general measure of the extent and the distribution of the supportive and supervisory leadership functions within the leadership team, we calculated two new variables: (a) maximum leadership, and (b) formal distribution of leadership functions (Conger \& Pearce, 2003; Mayo, Meindl, \& Pastor, 2003). These variables measure (a) the extent to which support and supervision are performed by the leadership team, and (b) the 
degree to which the two leadership functions are equally distributed across members of the leadership team.

a) Maximum leadership. To determine the amount of support and supervision performed by the leadership team, the maximum value of each item or the scores of the highest rated individual (i.e., the principal, the assistant principals or the teacher leaders) is used. The maximum leadership reflects the perceived performance of only one group of the leadership team: the group which is perceived as the most involved in the performance of the leadership functions. Therefore, the maximum leadership score represents the total or the maximum amount of the leadership functions. The score varies from 0 (never) to 4 (always).

b) Formal distribution of leadership functions. For the formal distribution of the leadership functions we assessed the centralization of the leadership team. This distribution of leadership refers to the degree to which the two leadership functions are equally distributed across members of the leadership team. The score has a range from 0 to 6 , and the highest score stands for equal distribution of the leadership functions among the principal, assistant principals, and teacher leaders.

\section{Measurement of the cohesive leadership team}

In the second part of the questionnaire, respondents are asked how they perceive the cohesion of the leadership team. To measure this concept we used validated subscales of role ambiguity (Rizzo, House, \& Lirtzman, 1970), group cohesion (Litwin \& Stringer, 1968), and the degree of goal consensus (Staessens, 1990). Participants are asked to rate each statement on a five-point Likert scale ranging from 0 (strongly disagree) to 4 (strongly agree). Exploratory and confirmatory factor analyses resulted in a satisfactory one factor structure $\left[\chi^{2}=138.098(d f\right.$ $=35 ; p<.000), \mathrm{CFI}=0.978, \mathrm{TLI}=0.972, \mathrm{SRMR}=0.026, \mathrm{RMSEA}=0.056]$. The internal reliability is high: $\alpha=0.93$. 


\section{Measurement of participative decision-making}

Also in the second part of the questionnaire, respondents are asked how they perceive the participation of school members in decision-making in the school. The validated subscale of Leithwood and Jantzi (1999), developing structures to foster participation in school decisions, was applied to asses this. Participants are asked to rate each statement on a five-point Likert scale ranging from 0 (strongly disagree) to 4 (strongly agree). Exploratory and confirmatory factor analyses revealed a satisfactory model $\left[\chi^{2}=57.403(d f=9 ; p<.000), \mathrm{CFI}=0.970, \mathrm{TLI}=\right.$ $0.950, \mathrm{SRMR}=0.032, \mathrm{RMSEA}=0.075]$. The internal reliability of the scale participative decision-making is 0.81 .

\section{Measurement of organizational commitment and job satisfaction}

The final part of the questionnaire is based on the validated subscale general professional wellbeing developed by Aelterman, Verhaeghe, and Engels (2002). This scale measures the job satisfaction of teachers and teacher leaders. Aelterman et al. (2007, p. 186) defined general professional wellbeing as 'a positive emotional state that is the result of a harmony between the sum of specific context factors on the one hand and the personal needs and expectations towards the school on the other hand.' This definition of general professional wellbeing is similar to Locke's (1976) definition of job satisfaction. In order to assess the organizational commitment, a translation of the organizational commitment questionnaire (Mowday et al., 1979) is used. Participants rate each statement on a five-point Likert scale ranging from 0 (strongly disagree) to 4 (strongly agree). Exploratory and confirmatory factor analyses resulted in a two factor structure $\left[\chi^{2}=152.08(d f=43 ; p<.000), \mathrm{CFI}=0.978, \mathrm{TLI}=\right.$ $0.972, \mathrm{SRMR}=0.031, \mathrm{RMSEA}=0.054]$. The internal consistency of organizational commitment is 0.91 . The internal consistency of job satisfaction is 0.79 . 


\subsection{Procedure}

First, an initial interview with the principal of the selected schools was conducted. In this interview the purpose of the research was explained and basic information about the school and the management structure was requested. Next, the questionnaires were handed to all principals, assistant principals, teacher leaders, and the teachers of the second stage (i.e., 1416-year-old pupils) of 46 secondary schools in Flanders (Belgium). All participants received a cover letter explaining the study purpose, procedures, and the methods in place to protect the anonymity of all respondents.

\subsection{Sample}

The 46 schools were selected from a list of 360 schools provided by the Flemish Ministry of Education. To select the schools we used stratified random sampling, taking the geographic regions (i.e., the five districts of Flanders) and the educational network (i.e., community, subsidized private, subsidized public) into account. Each school selected for this study had a minimum of 600 pupils, because these schools can appoint an assistant principal, which provides opportunities for distributed leadership.

The mean school size was 977 pupils (minimum 600, maximum 2930) and 121 teachers (minimum 55, maximum 410). The number of leadership team members was minimum 3 and maximum 23, with a mean of 11 . The mean job experience of the principal was 9.7 years, with a minimum of .5 and a maximum of 29 years.

A total of 2198 respondents, representing a response rate of $69 \%$, completed the questionnaire. Two hundred and ninety six respondents had more than $10 \%$ missing data and were removed from the analysis. In this study we focus on the responses of the teachers $(\mathrm{n}=$ $1522)$ and the teacher leaders $(n=248)$. The sample of teachers and teacher leaders included $43.5 \%$ male and $56.5 \%$ female, which is similar to the male-female division in the Flemish population of school members (43\% and $57 \%$ respectively). The age of the teachers and teacher 
leaders ranged from 22 years to 65 years, with an average age of 40 years. The mean length of time in their current job was 13 years, ranging from 0.1 to 40 years. The demographic variables for the teachers and the teacher leaders are represented in Table 1.

\section{$<<$ INSER TABLE 1 AROUND HERE $>>$}

\subsection{Data analysis}

First, descriptive statistics of the study variables were analyzed in order to answer the first research question. Second, multiple regression analyses in SPSS were used to explore the relation between the independent variables (i.e., maximum leadership functions, formal distribution of leadership functions, cohesive leadership team, participative decision-making, and context variables) and the dependent variables (i.e., organizational commitment and job satisfaction of teachers and teacher leaders). Based on the theoretical assumptions and the results of the regression analyses, a final model was examined using path analysis in AMOS. We opted for path analysis for two reasons. First, we wanted to investigate both the direct and the indirect relations between the independent variables, and organizational commitment and job satisfaction. Second, we wanted to examine the reciprocal relation between organizational commitment and job satisfaction.

\section{Results}

\subsection{Descriptive statistics of the study variables}

Table 2 shows that, according to teachers and teacher leaders, the principal is the main actor in supporting $(\mathrm{M}$ total $=2.62)$ and supervising school members $(\mathrm{M}$ total $=2.66)$. Also, the assistant principal is involved in both leadership functions ( $\mathrm{M}$ total support $=2.48$; $\mathrm{M}$ total supervision $=2.16)$. The teacher leaders are involved in supporting teachers $(\mathrm{M}$ total $=2.32)$, but their supervision of teachers is limited $(\mathrm{M}$ total $=1.40)$. The mean scores of teachers and teacher leaders (M total) concerning the maximum leadership (or the highest rated score for the 
leadership functions of the principal, assistant principals, and teacher leaders) is 2.90 for supervision, and 2.95 for support. The mean rating of distribution of leadership scores as perceived by the teachers and teacher leaders varies from 4.33 ( $\mathrm{M}$ total supervision) to 5.13 (M total support). These results suggest that, according to teachers and teacher leaders, supportive leadership is highly distributed and, as was expected, supervision is less equally distributed than support. The results in Table 2 also suggest that leadership teams are mainly perceived as cohesive $(\mathrm{M}$ total $=2.71)$ and that the participative decision-making is valued moderately positively $(\mathrm{M}$ total $=2.47)$. In terms of the outcome variables, the results show that teachers and teacher leaders feel committed to the school $(\mathrm{M}$ total $=3.00)$ and are satisfied with their job $(\mathrm{M}$ total $=3.07)$.

The descriptive statistics, represented in Table 2, also show that, in general, teacher leaders have a higher score on the research variables than teachers, with the exception of the distribution of supervision, and the supervision performed by the principals and the teacher leaders. This implies that teachers perceive teacher leaders to be more involved in supervision than teacher leaders see themselves involved in this leadership function. Finally, teachers have higher scores for job satisfaction than teacher leaders.

\section{$<$ INSERT TABLE 2 AROUND HERE $>>$}

\subsection{The relation between the study variables}

To explore the relation between the independent variables and the organizational commitment and job satisfaction of teachers and teacher leaders, we first applied multiple regression analyses. Taking research question two and three into account, we entered the study variables in three blocks in the regression analyses: (1) the demographic variables, (2) the school variables, and (3) the leadership variables (i.e., perceptions of the respondents regarding maximum leadership, formal distribution of leadership functions, cohesive leadership team, and participative decision-making). The position of the respondents was scored as a dummy 
variable (i.e., teacher $=1$, teacher leader $=0$ ). Table 3 represents the three blocks of predictor variables entered into the two models.

\section{<< INSERT TABLE 3 AROUND HERE >>}

\section{Multiple regression analysis: direct relation with organizational commitment}

The multiple regression analysis of the model on organizational commitment indicates that the context variables and the leadership variables explain $47.0 \%$ of the variance [Adjusted $\left.\mathrm{R}^{2}=.470, \mathrm{~F}(11,1693)=138.3931 * * *, p<.001\right]$

As the adjusted $\mathrm{R}^{2}$ change in Table 3 illustrates, the demographic and school variables only play a small role in predicting organizational commitment (adjusted $\mathrm{R}^{2}$ demographics $=$ .044 ; adjusted $\mathrm{R}^{2}$ school $=.012$ ). For the demographic variables, years of job experience negatively predicts organizational commitment. This indicates that the longer respondents perform their job, the lower their organizational commitment is.

The adjusted $\mathrm{R}^{2}$ change of the leadership variables (adjusted $\mathrm{R}^{2}$ leadership $=.414$ ) shows that the leadership variables are the most important independent variables in relation to organizational commitment. Based on the standardized regression coefficients $(\beta)$ the regression analysis suggests that cohesive leadership team and maximum support are the most important variables in the explanation of organizational commitment. Next, participative decision-making and the formal distribution scores for the supportive and supervisory leadership function are also significant variables for organizational commitment. Remarkably, the formal distribution of supervision has a significant negative influence on organizational commitment. This implies that the more supervision is distributed among the leadership team, the lower the organizational commitment of teachers and teacher leaders is. The maximum score of the supervisory leadership function does not contribute to organizational commitment. 
The multiple regression analysis of the model on job satisfaction indicates that the study variables explain only $11.7 \%$ of the variance [Adjusted $\mathrm{R}^{2}=.117, \mathrm{~F}(11,1693)=21.500 * * *, p<$ .001]. Table 3 shows that context variables have a small significant influence on job satisfaction (adjusted $\mathrm{R}^{2}$ change demographics $=.028$; adjusted $\mathrm{R}^{2}$ change school $\left.=.005\right)$. The leadership variables are the most important variables related to job satisfaction (adjusted $\mathrm{R}^{2}$ change leadership $=.084)$.

In terms of the demographic variables the regression analysis reveals that the position of the respondent is significantly related to job satisfaction: teachers are more satisfied with their job than their colleagues who perform extra leadership functions. Years of job experience is negatively related to job satisfaction: the longer a respondent performs his/her job, the lower his/her job satisfaction will be. This finding implies that scores on job satisfaction differ significantly in terms of work experience, which is similar to the model with organizational commitment as dependent variable. The principal's years of job experience is the only school context variable which is related to job satisfaction, however, this is only significant at the 5\%level.

The regression analysis also reveals that cohesive leadership team and the maximum and distribution score of the supportive leadership are significantly associated with job satisfaction. Participative decision-making is not significantly related to job satisfaction, nor is the supervisory leadership function. Again, the cohesion of the leadership team and maximum support are the most important variables associated with job satisfaction, and the formal distributions of the two leadership functions have a weaker relation with job satisfaction.

Path analysis: direct and indirect relations with organizational commitment and job satisfaction, and the reciprocal relation between organizational commitment and job satisfaction 
Based on the theoretical framework and the statistical results of the multiple regression analyses, general conclusions can be made concerning the direct relations between the independent variables, and the teachers' and teachers leaders' organizational commitment on the one hand, and the job satisfaction on the other hand. However, indirect relations and the reciprocal association between the dependent variables remain unexplored. Therefore, path analysis is applied to assess the final research model. Special attention is paid to the relation between organizational commitment and job satisfaction. The reciprocal relation between organizational commitment and job satisfaction is examined by direct feedback loops. This leads to a non-recursive model. Both the order and the rank conditions are met (Kline, 2005). Also the assumption of equilibrium is met (stability index $=.64<1)($ Kline, 2005).

Only the significant variables, which occurred in the explorative regression analyses, are entered into the model. This model reveals satisfactory model fit results $\left[\chi^{2}=37.7(d f=11, p<\right.$ $.000) ; \mathrm{CFI}=.994 ; \mathrm{TLI}=.976 ; \mathrm{SRMR}=.022 ; \mathrm{RMSEA}=.038]$. However, there are insignificant regression weights between principal's years of experience, cohesive leadership team, maximum support, and distribution of support as exogenous variables, and job satisfaction as endogenous variable. This implies that, in contrast to the results of the multiple regression analysis, there are no significant direct relations between these variables and job satisfaction. We assume that these exogenous variables will have an indirect relation with job satisfaction, mediated by organizational commitment. A modified model, presented in Figure 2, is tested and reveals satisfactory fit results.

\section{$<<$ INSERT FIGURE 2 AROUND HERE >> $<<$ INSER TABLE 4 AROUND HERE $>>$}

The results of the path analysis, presented in Table 4, partially confirm the results of the multiple regression analyses: the research variables primarily influence organizational commitment; job satisfaction is less influenced by the study variables. Also, the perceptions of the cohesive leadership team and the maximum score of the supportive leadership function are 
the most important significant variables in relation to organizational commitment. In contrast, based on the results of the path analysis, we conclude that job satisfaction is mainly directly associated with the context variables: the position of the respondent (i.e., teacher versus teacher leader) and years of job experience. The direct influence of the leadership variables, which occurred as significant variables in the regression analysis, is not confirmed in the path analysis. Concerning the leadership variables, job satisfaction is mostly directly related to organizational commitment and indirectly related to cohesion of the leadership team and maximum support.

In terms of the reciprocal relation between organizational commitment and job satisfaction, Table 4 shows that there is a significant direct effect of job satisfaction on organizational commitment. However, this effect is much smaller than the effect of organizational commitment on job satisfaction.

\section{Discussion}

There has been a lack of empirical research on distributed leadership and its relation with the organizational commitment and job satisfaction of teachers and teacher leaders. In an attempt to fill this gap, we investigated the perceptions of teachers and teacher leaders $(\mathrm{n}=$ 1770) on distributed leadership. In addition to using multiple regression analyses, we also applied path analysis.

Our results indicated that the school principal is the most influential actor for the two leadership functions examined (i.e., support and supervision). The results also showed that supervision is the leadership function with the highest centralization, while supportive leadership is more equally distributed among principals, assistant principals, and teacher leaders. We conclude that formative evaluation of teachers tends to involve only one or two leaders (typically the principal and/or the assistant principals). In contrast, supportive 
leadership practices, such as teacher development, involve more leaders. This is in line with the findings of Spillane (2006). In terms of the perceptions of teachers and teacher leaders on the leadership team, our results showed that the leadership team is quite cohesive. Furthermore, teachers and teacher leaders believed that they can moderately participate in school decisionmaking. Our results also indicated that teachers and teacher leaders feel highly committed to the school and are very satisfied in their job. This finding is in line with the research of Aelterman et al. (2007) and Nguni et al. (2006).

The multiple regression analyses and the path analysis showed that the independent variables mainly explain the organizational commitment of teacher and teacher leaders. A weak relation between the independent variables and job satisfaction was found. We can therefore conclude that variables concerning the leadership in schools will have a greater direct relation to the degree to which an individual feels loyal and can identify with and involve in schools, than to the positive emotions toward the job. Other factors than the distributed school leadership are assumed to influence teachers' and teacher leaders' job satisfaction (e.g., Dinham \& Scott, 2000; Vandenberghe \& Huberman, 1999).

Our results also showed that a cohesive leadership team and the maximum amount of support a teacher receives from the leadership team are the most important variables associated with organizational commitment and job satisfaction. There is a strong direct relation between both independent variables and organizational commitment, and a strong indirect relation with job satisfaction, mediated by organizational commitment. As mentioned above, the relation between the perception of teachers and teacher leaders on the cohesion of their leadership team and their organizational commitment or job satisfaction was not often studied. Our findings suggested that the cohesion of the leadership team, defined here as a cohesive group with clear and unambiguous roles and shared goals, is strongly related to organizational commitment. This implies that teachers and teacher leaders who believe that their school is led by a cohesive leadership team will be more committed towards the school and be more satisfied with their 
job, compared to teachers and teacher leaders who perceive their leadership team as less cohesive. Furthermore, our findings showed that the supportive leadership function has a strong link with organizational commitment and job satisfaction, which corroborates previous research (Currivan, 1990; Nguni et al., 2006; Singh \& Billingsley, 1998). This implies that teachers and teacher leaders who feel supported will be highly committed towards the school and be very satisfied with their job.

We also found that participative decision-making is positively related with the teachers' and teacher leaders' organizational commitment. These results confirm earlier studies which argue that participation in decision-making increases an individual's commitment to the organization (Kushman, 1992). This relation is, however, less strong than the relation between a cohesive leadership team and the maximum amount of support. Furthermore, there is no significant relation between participative decision-making and job satisfaction, which confirms the results of Taylor and Tashakkori (1995). Thus, our study suggested that the cohesion of the leadership team and leadership support are more important for teachers' and teacher leaders' commitment and job satisfaction than the participation in school decision-making.

Next, we found that the formal distribution of supportive leadership among the leadership team is related to teachers' and teacher leaders' organizational commitment and job satisfaction. However, this relationship is less strong than the relation with a cohesive leadership team, maximum support, and participative decision-making. This implies that it is not important for teachers or teacher leaders that the supportive leadership function is strongly distributed among the leadership team. More important is that the leadership team functions in a cohesive way, and that teachers and teacher leaders receive sufficient support. It seems irrelevant whether this support is mainly provided by one member of the leadership team or whether support is strongly distributed among many formal leaders.

Our findings also indicated that supervision is a leadership function that plays a limited role in the organizational commitment and job satisfaction of teachers and teacher leaders. We 
found that the maximum amount of supervision was not significantly related to organizational commitment or to job satisfaction. This implies that schools, in which the performance of the staff is regularly evaluated, or where there are often formative and summative evaluations, do not necessarily have more committed or satisfied teachers or teacher leaders. Furthermore, our results showed that there is a marginal negative relation between the distribution of the supervisory leadership function, and organizational commitment and job satisfaction. This implies that teachers and teacher leaders who are supervised by only one person may be more committed to the school and satisfied with their job, than teachers supervised by multiple school leaders. A possible explanation is that supervision by multiple school leaders can lead to contradictory feedback on the performance of teachers given by the different school leaders. Such inconsistency may confuse teachers and teacher leaders, and have a negative impact on their organizational commitment and job satisfaction. Teachers and teacher leaders prefer clear and unambiguous supervision provided by one member of the school team, presumably the principal.

In terms of the context variables used in this study, we found that the years of job experience of teachers or teacher leaders is negatively related to both organizational commitment and job satisfaction. This result supports the view of Brunetti (2001) who maintained that more experienced teachers feel less committed to the organization and less satisfied in their job than less experienced teachers. Being a teacher or a teacher leader was expected to have an influence on both organizational commitment and job satisfaction. However, our results only confirmed the hypothesis that teacher leaders are less satisfied with their job than the classroom teachers. This can possibly be explained by the extra workload or the unclear role of teacher leaders (Smylie, 1999). The results from our regression analyses indicated that the principal's years of job experience, which can be interpreted as 'principal stability,' is considered to be significantly related with teachers' and teacher leaders' job satisfaction, which confirms the study of Mayrowetz et al. (2007). However, the results of the 
path analysis did not support this finding. Therefore, in our final model the principal's job experience was not related with organizational commitment or with the job satisfaction of teachers or teacher leaders.

Finally, in our study we found that organizational commitment and job satisfaction are reciprocally related (Mathieu, 1991) and that organizational commitment mainly influences job satisfaction (Culver, Wolfle, \& Cross, 1990; Vandenbergh \& Lance, 1992). We conclude that, organizational commitment and job satisfaction are intertwined. Hence, it is difficult to measure them separately. However, as these variables are differently related with the study variables, treating them as separate entities would be interesting for future research.

\section{Conclusion}

The present study confirmed Gronn's (2002) and Spillane's (2006) theory of distributed leadership that the leader-plus aspect or the numerical action is an essential, but not a sufficient aspect of distributed leadership. The leadership practice is more than the aggregation of individual leaders' labour (Spillane, 2006). This study showed that the cohesion of the leadership team and the maximum amount of support have a higher impact on teachers' and teachers leaders' organizational commitment than the formal distribution of leadership functions. Therefore, the formal distribution of leadership functions should not be an aim in itself. A cohesive leadership team, with strong support in schools, and limited formal distribution of the leadership functions will be more positively related with the organizational commitment of teachers and teacher leaders, than schools without a cohesive leadership team, limited support, and a high formal distribution of the leadership.

Our study contains certain limitations, which indicate the need for more extensive research in this domain. First, the study is limited to the distribution of two leadership functions (i.e., support and supervision) in large secondary schools. It would be interesting to investigate the distribution of other leadership functions (e.g., building management functions, boundary 
spanning functions) or certain subject matters (Spillane, 2006). Furthermore, distributed leadership in smaller secondary schools or other educational levels, like primary or higher education, which are characterized by different management structures, should be studied. Second, the number of context variables used in our study was limited. Although the results show a satisfactory research model, other important variables were not included in the study. Particularly variables at school level, such as organizational stability (Mayrowetz et al., 2007) or development stage (Spillane, 2006) might also be considered as relevant factors of organizational commitment or job satisfaction and should be examined. A third limitation concerns the quantitative nature of the research instrument. To extend the present research methodology, future research should collect in depth information through qualitative research methods, such as interviews or participant observation. A final limitation of this study is the assumed independence of individuals as unit of analysis. It may be interesting to continue this investigation using a multilevel approach, which takes the hierarchical structure of teachers nested within schools into account.

Despite the limitations, the current study has important theoretical implications for the school effectiveness and improvement literature. A first theoretical implication is the clarification of the concept distributed leadership. In this study we defined distributed leadership from three perspectives: (1) the formal distribution of the supportive and supervisory leadership functions, (2) the cohesive leadership team, which refers to the interaction that takes place among the leadership team members, and (3) participative decision-making of the whole school team, which refers to the informal contribution of all school employees in the decisionmaking process of the school. Also, the use of a reliable and valid instrument to measure distributed leadership, which was lacking in previous research, is an important strength of the present study. Furthermore, the present study sheds light on the relationship between distributed leadership and organizational commitment and job satisfaction. Since distributed leadership has become a buzz-word during the last decade, it is important to investigate its relation with 
organizational outcome variables, like commitment and satisfaction, which can lead to more effective schools.

The present study also points towards practical implications for schools. It suggests that to increase the level of organizational commitment and job satisfaction of teachers and teacher leaders, large schools need to invest in the cohesion among the leadership team members. This implies that in large schools the leadership team must lead the school in a collaborative and interactive way. This can be attained by defining clear roles for the different team members, developing an open communication where all members can speak freely and share the same school goals. In defining the roles of the different team members these elements are more important than a highly formal distribution of leadership functions and the participation of teachers in school decision-making. This has practical implications for the selection and the inservice training of school leaders. School leaders should not only be solid experts in managing a school, they also have to learn to work in concert with their colleagues. This means it is important to attract school leaders that fit well with the other team members. When the leadership team loses its cohesion, the distribution of leadership can result in a lower teacher commitment. Furthermore, school leaders should provide sufficient support to teachers and teacher leaders. Although this is off course a time-consuming task, this should be a mission of the whole leadership team. Also, school leadership teams must realize that not all leadership tasks must be distributed. The development of a school vision and support are important leadership functions that indeed should be distributed. However, supervision of teachers must be concentrated within one leader. 


\section{Notes on contributors}

Hester Hulpia is a Ph.D. candidate in education at the Department of Educational Studies, Ghent University (Belgium). Her dissertation research concerns distributed leadership in secondary schools, antecedents of distributed leadership and the impact of leadership on teachers' well-being and teachers' organizational commitment.

Geert Devos, Ph.D., is a professor in educational administration and organizational behavior at the Ghent University (Belgium), the Vrije Universiteit Brussel (Belgium) and the University of Antwerp (Belgium). His current research areas include educational leadership, school-based self-evaluation and readiness to organizational change.

Yves Rosseel, Ph.D., is a professor in data-analysis at the Ghent University (Belgium). His current research area includes applied data analysis. 


\section{References}

Aelterman, A., Engels, N., Van Petegem, K., \& Verhaeghe, J.P. (2007). The well-being of teachers in Flanders: The importance of a supportive school culture. Educational Studies, 33, 285-297.

Aelterman, A., Verhaeghe, J.P., \& Engels, N. (2002). Het welbevinden van de leerkracht: De ontwikkeling van een bevragingsinstrument voor het meten van het welbevinden van leerkrachten basis- en secundair onderwijs [The wellbeing of teachers: The development of a research instrument to measure the wellbeing of teachers in primary and secondary education]. (Rep. No. OBPWO-project 00.06). Gent - Brussel, Belgium: Universiteit Gent - Vrije Universiteit Brussel.

Bamburg, J., \& Andrews, R. (1990). School goals, principals and achievement. School Effectiveness and School Improvement, 2, 175-191.

Barnett, K., \& McCormick, J. (2003). Vision, relationships and teacher motivation: A case study. Journal of Educational Administration, 41, 55-73.

Barry, D. (1991). Managing the bossless team: Lessons in distributed leadership. Organizational Dynamics, 21, 31-47.

Bass, B.M. (1985). Leadership and performance beyond expectations. New York: The Free Press.

Bennett, N., Newton, W., Wise, C., Woods, P.A., \& Economou, A. (2003). The role and purpose of middle leaders in schools (Full report). Nottingham, UK: National College for School Leadership.

Bennett, N., Wise, C., Woods, P., \& Harvey, J.A. (2003). Distributed leadership (Full report). Nottingham, UK: National College for School Leadership.

Blase, J. \& Blase, J. (2002). The micropolitics of instructional supervision: A call for research. Educational Administration Quarterly, 38, 6-44. 
Boardman, M. (2001). The value of shared leadership: Tasmanian teachers' and leaders' differing views. International Studies in Educational Administration, 29, 2-10.

Bogler, R. (2001). The influence of leadership style on teacher job satisfaction. Educational Administration Quarterly, 37, 662-683.

Bogler, R. (2005). Satisfaction of Jewish and Arab teachers in Israel. The Journal of Social Psychology, 145, 19-33.

Bogler, R., \& Somech, A. (2004). Influence of teacher empowerment on teachers' organizational commitment, professional commitment and organizational citizenship behavior in schools. Teaching and Teacher Education, 20, 277-289.

Briggs, K.L., \& Wohlstetter, P. (2003). Key elements of a successful school-based management strategy. School Effectiveness and School Improvement, 14, 351-372.

Brunetti, G.J. (2001). Why do they teach? A study of job satisfaction among long term high school teachers. Teacher Education Quarterly, 28, 49-74.

Burns, J.M. (1978). Leadership. New York: Harper and Row.

Bush, T., \& Glover, D. (2003). School leadership: Concepts and evidence (Full Report). Nottingham, UK: National College for School Leadership.

Byrne, B.M. (1999). The nomological network of teacher burnout: A literature review and empirically validated model. In R. Vandenberghe \& A.M. Huberman (Eds.), Understanding and preventing teacher burnout. A sourcebook of international research and practice (pp. 15-38). Cambridge, UK: University Press.

Camburn, E., Rowan, B., \& Taylor, J.E. (2003). Distributed leadership in schools: The case of elementary schools adopting comprehensive school reform models. Educational Evaluation and Policy Analysis, 25, 347-373.

Chrispeels, J., Castillo, S., \& Brown, J. (2000). School leadership teams: A process model of team development. School Effectiveness and School Improvement, 11, 20-56. 
Chrispeels, J., \& Yep, M. (2004, April). Principals and teachers reflect on sharing leadership.

Paper presented at the Annual Meeting of the American Educational Research Association. San Diego, CA.

Conger, J.A., \& Pearce, C.L. (2003). A landscape of opportunities. In C.L. Pearce \& J.A. Conger (Eds.), Shared leadership. Reframing the hows and whys of leadership (pp. 285303). Thousand Oaks, CA: Sage.

Copland, M.A. (2001). The myth of the superprincipal. Phi Delta Kappan, 82, 528-533.

Copland, M.A. (2003). Leadership of inquiry: Building and sustaining capacity for school improvement. Educational Evaluation and Policy Analysis, 25, 375-395.

Culver, S.M., Wolfle, L.M., \& Cross, L.H. (1990). Testing a model of teacher satisfaction for blacks and whites. American Educational Research Journal, 27, 323-349.

Currivan, D.B. (1999). The causal order of job satisfaction and organizational commitment in models of employee turnover. Human Resource Management Review, 9, 495-524.

De Maeyer, S., Rymenans, R., Van Petegem, P., van den Bergh, H., \& Rijlaarsdam, G. (2007). Educational leadership and pupil achievement. The choice of a valid conceptual model to test effects in school effectiveness research. School Effectiveness and School Improvement, 18, 125-146.

Dee, J.R., Henkin, A.B., \& Singleton, C.A. (2006). Organizational commitment of teachers in urban schools: Examining the effects of team structures. Urban Education, 41, 603-627.

Dinham, S., \& Scott, C. (2000). Moving into third: Outer domain of teacher satisfaction. Journal of Educational Administration, 38, 379-396.

Eden, D. (2001). Who controls teachers? Overt and covert control in schools. Educational Management and Administration, 29, 97-111.

Elmore, R.F. (2000). Building a new structure for school leadership. Washington, DC: Albert Shanker Institute. 
Evans, V., \& Johnson, D.J. (1990). The relationship of principals' leadership behavior and teachers' job satisfaction and job-related stress. Journal of Instructional Psychology, 17, 11-19.

Farkas, A., \& Tetrick, L. (1989). A three-wave longitudinal analysis of the causal ordering of satisfaction and commitment in turnover decisions. Journal of Applied Psychology, 47, $855-868$.

Firestone, W.A. (1996). Leadership roles or functions. In K. Leithwood, D. Chapman, P. Corson, P. Hallinger, \& W. Hart (Eds.), International handbook of educational leadership and administration (pp. 395-418). Dordrecht, The Netherlands: Kluwer Academic.

Firestone, W.A., \& Pennell, J.R. (1993). Teacher commitment, working conditions and differential incentive policies. Review of Educational Research, 63, 489-525.

Firestone, W.A., \& Martinez, M.C. (2007). Districts, teacher leaders, and distributed leadership: Changing instructional practice. Leadership and Policy in Schools, 6, 3-35.

French, J.R.P., \& Caplan, R.D. (1972). Organizational stress and individual strain. In A.J. Marrow (Ed.), The failure of success (pp. 30-67). New York: Amacom.

Fresko, B., Kfir, D., \& Nasser, F. (1997). Predicting teacher commitment. Teaching and Teacher Education, 13, 429-438.

Goldstein, J. (2003). Making sense of distributed leadership: The case of peer assistance and review. Educational Evaluation and Policy Analysis, 25, 397-421.

Goleman, D. (2002). The new leaders: Transforming the art of leadership into science of results. London: Little Brown.

Gronn, P. (2002). Distributed leadership. In K. Leithwood \& P. Hallinger (Eds.), Second international handbook of educational leadership and administration (pp. 653-696). Dordrecht, The Netherlands: Kluwer Academic. 
Grubb, W.N., \& Flessa, J.J. (2006). A job too big for one: Multiple principals and other nontraditional approaches to school leadership. Educational Administration Quarterly, $42,518-550$.

Hallinger, P. (2003). Leading educational change: Reflections on the practice of instructional and transformational leadership. Cambridge Journal of Education, 33, 329-351.

Hallinger, P., \& Murphy, J. (1985). Assessing the instructional behavior of principals. Elementary School Journal, 86, 217-248.

Harris, A. (2005). Distributed leadership and school improvement: Leading or misleading? Journal of Curriculum Studies, 37, 255-265.

Harris, A., \& Muijs, D. (2003). Teacher leadership: Improvement through empowerment? An overview of the literature. Educational Management and Administration, 31, 437-448.

Harris, A., \& Muijs, D. (2005). Improving schools through teacher leadership. Berkshire, UK: Open University Press.

Heller, M.J., \& Firestone, W.A. (1995). Who's in charge here? Sources of leadership for change in eight schools. The Elementary School Journal, 96, 65-86.

Hersey, P., \& Blanchard, K. (1993). Management of organizational behavior: Utilizing human resources. (6th ed.). Englewood Cliffs, NJ: Prentice Hall.

Holtz, R. (2004). Group cohesion, attitude projection, and opinion certainty: Beyond interaction. Group Dynamics: Theory, Research and Practice, 8, 112-125.

Horn, J.L. (1965). A rationale and test for the number of factors in factor analysis. Psychometrika, 30, 179-185.

Hoy, W.K., \& Tarter, C.J. (1997). The road to open and healthy schools: A handbook for change. Thousand Oaks, CA: Corwin Press.

Hoy, W.K., Tarter, C.J., \& Bliss, J.R. (1990). Organizational climate, school health, and effectiveness: A comparative analysis. Educational Administration Quarterly, 26, 260279. 
Hulpia, H., Devos, G., \& Rosseel, Y. (in press). Development and validation of scores on the distributed leadership inventory. Educational Psychological Measurement.

Kilcher, C. (1992). Becoming a change facilitator: The first-year experience of five teacher leaders. In C. Livingston (Ed.), Teachers as leaders (pp. 91-113). Washington, DC: National Education Association.

Kline, R. B. (2005). Principals and practice of structural equation modeling ( $2^{\text {nd }}$ Ed.). New York: The Guilford Press.

Koh, W.L., Steers, R.M., \& Terborg, J.R. (1995). The effects of transformational leadership on teacher attitudes and student performance in Singapore. Journal of Organizational Behavior, 16, 319-333.

Kushman, J.W. (1992). The organizational dynamics of teacher workplace commitment: A study of urban elementary and middle schools. Educational Administration Quarterly, $28,5-42$.

Lashway, L. (2003). Distributed leadership. Eugene, OR: ERIC Clearinghouse on Educational Management.

Leithwood, K., \& Jantzi, D. (1999). Transformational school leadership effects: A replication. School Effectiveness and School Improvement, 10, 451-479.

Leithwood, K., \& Jantzi, D. (2000). The effects of different sources of leadership on student engagement in school. In K.A. Riley \& K.S. Louis (Eds.) Leadership for change and school reform. International perspectives (pp. 50-66). London: Routledge.

Leithwood, K., Jantzi, D., \& Steinbach, R. (1999). Changing leadership for changing times. Buckingham, UK: Open University Press.

Leithwood, K., Mascall, B., Strauss, T., Sacks, R., Memon, N., \& Yashkina, A. (2007). Distributing leadership to make schools smarter: Taking the ego out of the system. Leadership and Policy in Schools, 6, 37-67. 
Leithwood, K., \& Riehl, C. (2003, April). What do we really know about successful school leadership? Paper presented at the Annual Meeting of the American Educational Research Association. Chicago, IL.

Liontos, L.B., \& Lashway, L. (1997). Shared decision-making. In S.C. Smith \& P.K. Piele (Eds.), School leadership: Handbook for excellence (pp. 226-250). Eugene, OR: ERIC Clearinghouse on Educational Management.

Litwin, G.H., \& Stringer, R.A. (1968). Motivation and organizational climate. Boston: Harvard University Press.

Locke, E.A. (1976). The nature and causes of job satisfaction. In M.D. Dunnette (Ed.), Handbook of industrial and organizational psychology (pp. 1293-1349). Chicago, IL: Rand McNally.

Locke, E.A. (2003). Leadership: Starting at the top. In C.L. Pearce \& J.A. Conger (Eds.), Shared leadership: Reframing the hows and whys of leadership (pp. 271-284). Thousand Oaks, CA: Sage.

Louis, K.S. (1998). Effects of teacher quality of work life in secondary schools on commitment and sense of efficacy. School Effectiveness and School Improvement, 9, 1-27.

Macbeath, J. (2005). Leadership as distributed: A matter of practice. School Leadership and Management, 25, 349-366.

Maeroff, G. (1988). The empowerment of teachers. New York: Teachers College Press.

Mathieu, J.E. (1991). A cross-level nonrecursive model of the antecedents of organizational commitment and satisfaction. Journal of Applied Psychology, 76, 607-618.

Mathieu, J.E., \& Zajac, D.M. (1990). A review and meta-analysis of the antecedents, correlates, and consequences of organizational commitment. Psychological Bulletin, 108, 171-194.

Mayo, M., Meindl, J.R., \& Pastor, J.C. (2003). Shared leadership in work teams: A social network approach. In C.L. Pearce \& J. A. Conger (Eds.), Shared leadership: Reframing the hows and whys of leadership (pp. 193-214). Thousand Oaks, CA: Sage. 
Mayrowetz, D., Murphy, J., Louis, K.S., \& Smylie, M.A. (2007). Distributed leadership as work redesign: Retrofitting the job characteristics model. Leadership and Policy in Schools, 6, 69-101.

McGarvey, B., \& Marriott, S. (1997). The role of the core subject coordinator in supporting differentiation in Northern Ireland primary schools. School Leadership and Management, 17, 375-386.

Meyer, J.P., \& Allen, N.J. (1997). Commitment in the workplace: Theory, research, and application. Thousand Oaks, CA: Sage.

Morrison, K. (2002). School leadership and complexity theory. London: Routledge Falmer.

Mowday, R., Steers, R., \& Porter, L. (1979). The measurement of organizational commitment. Journal of Vocational Behavior, 14, 224-247.

Muijs, D., \& Harris, A. (2007). Teacher leadership in (in)action: Three case studies of contrasting schools. Educational Management Administration and leadership, 35, 111134.

Murphy, J. (2005). Connecting teacher leadership and school improvement. Thousand Oaks, CA: Corwin Press.

Neuman, M., \& Simmons, W. (2000). Leadership for student learning. Phi Delta Kappan, 82, $9-13$.

Nguni, S., Sleegers, P., \& Denessen, E. (2006). Transformational and transactional leadership effects on teachers' job satisfaction, organizational commitment, and organizational citizenship behavior in primary schools: The Tanzanian case. School Effectiveness and School Improvement, 17, 145-177.

Nir, A.E. (2002). School-based management and its effect on teacher commitment. International Journal of Leadership in Education, 5, 323-341.

Oduro, G.K.T. (2004). Distributed leadership in schools. Education Journal, 80, 23-25. 
Ostroff, C. (1992). The relationship between satisfaction, attitudes and performance: An organizational level analysis. Journal of Applied Psychology, 77, 963-974.

Oswald, L.J. (1997). School-based management. In S.C. Smith \& P. K. Piele (Eds.), School leadership. Handbook for excellence (pp. 181-203). Eugene, OR: ERIC Clearinghouse on Educational Management.

Pounder, D.G., Ogawa, R.T., \& Adams, E.A. (1995). Leadership as an organization-wide phenomena: Its impact on school performance. Educational Administration Quarterly, $31,564-588$.

Rayner, S., \& Gunter, H. (2005). Rethinking leadership: Perspectives on remodeling practice. Educational Review, 57, 151-161.

Reyes, P., \& Shin, H.S. (1995). Teacher commitment and job satisfaction: A causal analysis. Journal of School Leadership, 5, 22-39.

Rinehart, J.S., \& Short, P.M. (1994). Job satisfaction and empowerment among teacher leaders, reading recovery teachers and regular classroom teachers. Education, 114, 570-580.

Rizzo, J.R., House, R.J., \& Lirtzman, S.I. (1970). Role conflict and ambiguity in complex organizations. Administrative Science Quarterly, 15, 150-163.

Rosenholtz, S. (1989). Teachers' workplace: The social organization of schools. New York: Longman.

Scribner, J.P., Sawyer, R.K., Myers, V., \& Watson, T. (2004, April). Teacher teams and distributed leadership: A study of group creativity and collaboration. Paper presented at the Annual Meeting of the American Educational Research Association, San Diego: CA.

Singh, K., \& Billingsley, B.S. (1998). Professional support and its effects on teachers' commitment. The Journal of Educational Research, 91, 229-239.

Smith, S.C., \& Piele, P.K. (Eds.). (1997). School leadership. Handbook for excellence. Eugene, OR: ERIC Clearinghouse on Educational Management. 
Smylie, M.A. (1999). Teacher stress in a time of reform. In R. Vandenberghe \& A.M. Huberman (Eds.), Understanding and preventing teacher burnout. A sourcebook of international research and practice (pp. 59-85). Cambridge, UK: University Press.

Smylie, M.A., \& Brownlee-Conyers, J. (1992). Teacher leaders and their principals: Exploring the development of new working Relationships. Educational Administration Quarterly, $28,150-184$.

Somech, A. (2005). Directive versus participative leadership: Two complementary approaches to managing school effectiveness. Educational Administration Quarterly, 41, 777-800.

Somech, A., \& Drach-Zahavy, A. (2000). Understanding extra-role behavior in schools: The relationships between job satisfaction, sense of efficacy, and teachers' extra role behavior. Teaching and Teacher Education, 16, 649-659.

Southworth, G. (2002). Instructional leadership in schools: Reflections and empirical evidence. School Leadership and Management, 22, 73-91.

Spillane, J.P. (2006). Distributed leadership. San Francisco: Jossey-Bass.

Spillane, J.P., Diamond, J.B., \& Jita, L. (2003). Leading instruction: The distribution of leadership for instruction. Journal of Curriculum Studies, 35, 533-543.

Staessens, K. (1990). De professionele cultuur van basisscholen in vernieuwing. Een empirisch onderzoek in V.L.O.- scholen [The professional culture of improving elementary schools. An empirical research in VLO-schools]. Unpublished doctoral dissertation, KULeuven, Belgium.

Steinbach, R. (1996, April). Struggling to manage distributed leadership. Paper presented at the Annual Meeting of the American Educational Research Association. New York.

Tao, M., Takagi, H., Ishida, M., \& Masuda, K. (1998). A study of antecedents of organizational commitment. Japanese Psychological Research, 40, 198-205. 
Taylor, D.L., \& Tashakkori, A. (1995). Decision participation and school climate as predictors of job satisfaction and teachers' sense of efficacy. Journal of Experimental Education, 63, 217-231.

Timperley, H.S. (2005). Distributed leadership: Developing theory from practice. Journal of Curriculum Studies, 37, 395-420.

Vandenbergh, R.J., \& Lance, C.E. (1992). Examining the causal order of job satisfaction and organizational commitment. Journal of Management, 18, 153-167.

Vandenberghe, R., \& Huberman, A.M. (Eds.). (1999). Understanding and preventing teacher burnout: A sourcebook of international research and practice. Cambridge, UK: University Press.

Wasley, P. (1991). Teachers who lead: The rhetoric of reform and realities of practice. New York: Teachers College Press, Colombia University.

Wech, B.A., Mossholder, K.W., Steel, R.P., \& Bennett, N. (1998). Does work group cohesiveness affect individuals' performance and organizational commitment? A crosslevel examination. Small Group Research, 29, 472-494. 
Appendix. The Distributed Leadership Inventory (Hulpia, Devos, \& Rosseel, in press)

\begin{tabular}{ll}
\hline Scale & Item \\
& To what amount is (1) the principal; $(2)$ the assistant principals; (3) the teacher \\
& leaders involved in the following statements? (never/0; always/4) \\
\hline Support & $\ldots$ premises a long term vision \\
& $\ldots$ debates the school vision \\
& $\ldots$ compliments teachers \\
& $\ldots$ helps teachers \\
& $\ldots$ explains his / her reason for criticism to teachers \\
& $\ldots$ is available after school to help teachers when assistance is needed \\
& $\ldots$ looks out for the personal welfare of teachers \\
& $\ldots$ encourages me to pursue my own goals for professional learning \\
& $\ldots$ encourages me to try new practices consistent with my own interests \\
& $\ldots$ provides organizational support for teacher interaction \\
& $\ldots$ evaluates the performance of the staff \\
& $\ldots$ is involved in summative evaluation of teachers \\
& $\ldots$ is involved in formative evaluation of teachers
\end{tabular}

\begin{tabular}{ll}
\hline Scale & $\begin{array}{l}\text { Item } \\
\text { (strongly disagree/0; strongly agree/4) }\end{array}$ \\
\hline Cohesive & There is a well-functioning leadership team in our school \\
leadership team & The leadership team tries to act as well as possible \\
& The leadership team supports the goals we like to attain with our school \\
& All members of the leadership team work in the same strain on the school's core \\
objectives & In our school the right man sits on the right place, taken the competencies into \\
& account \\
Members of the management team / I divide their time properly \\
Members of the leadership team / I have clear goals \\
Members of the leadership team / I know which tasks they / I have to perform \\
The leadership team is willing to execute a good idea \\
It is clear where members of the leadership team are authorized to \\
\hline Participative & Leadership is delegated for activities critical for achieving school goals \\
decision-making & Leadership is broadly distributed among the staff \\
& We have an adequate involvement in decision making \\
& There is an effective committee structure for decision-making \\
& Effective communication among staff is facilitated \\
There is an appropriate level of autonomy in decision making
\end{tabular}

\begin{tabular}{ll}
\hline Scale & $\begin{array}{l}\text { Item } \\
\text { (strongly disagree/0; strongly agree/4) }\end{array}$ \\
\hline Organizational & My school inspires me to do the best I can \\
commitment & I'm proud to be a part of this school team \\
& I really care about the fate of this school \\
& I find that my values and the organization's values are very similar \\
& I regularly talk to friends about the school as a place where it is great to work \\
& I'm really happy that I chose this school to work for \\
\hline Job satisfaction & There is no better job than being a teacher / teacher leader \\
& I like to teach / perform my teacher leader function \\
& I want to stay in my current job \\
& If I could choose again, I would trade my job for an other profession (R)
\end{tabular}

Note: $\mathrm{R}=$ Reverse item. 
Figures

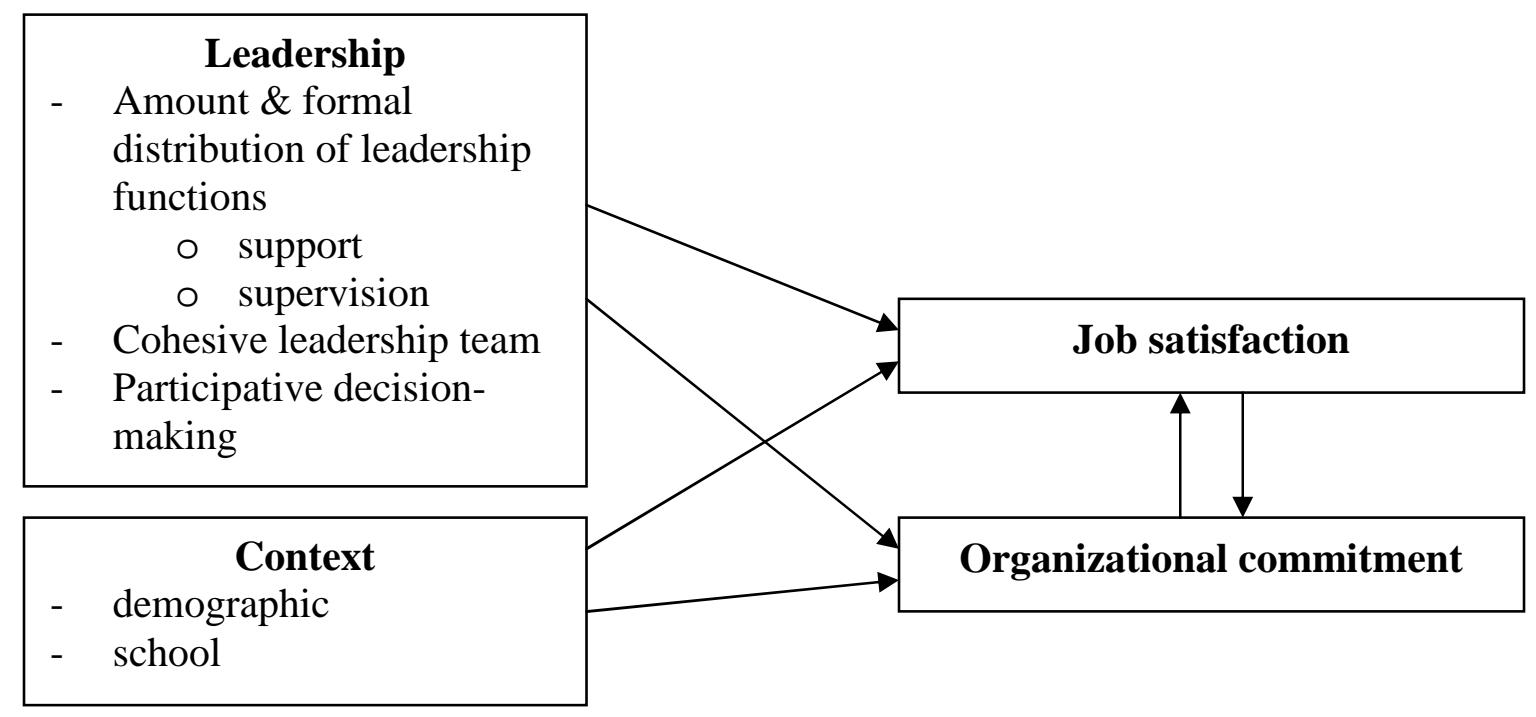

Figure 1. Research questions. 


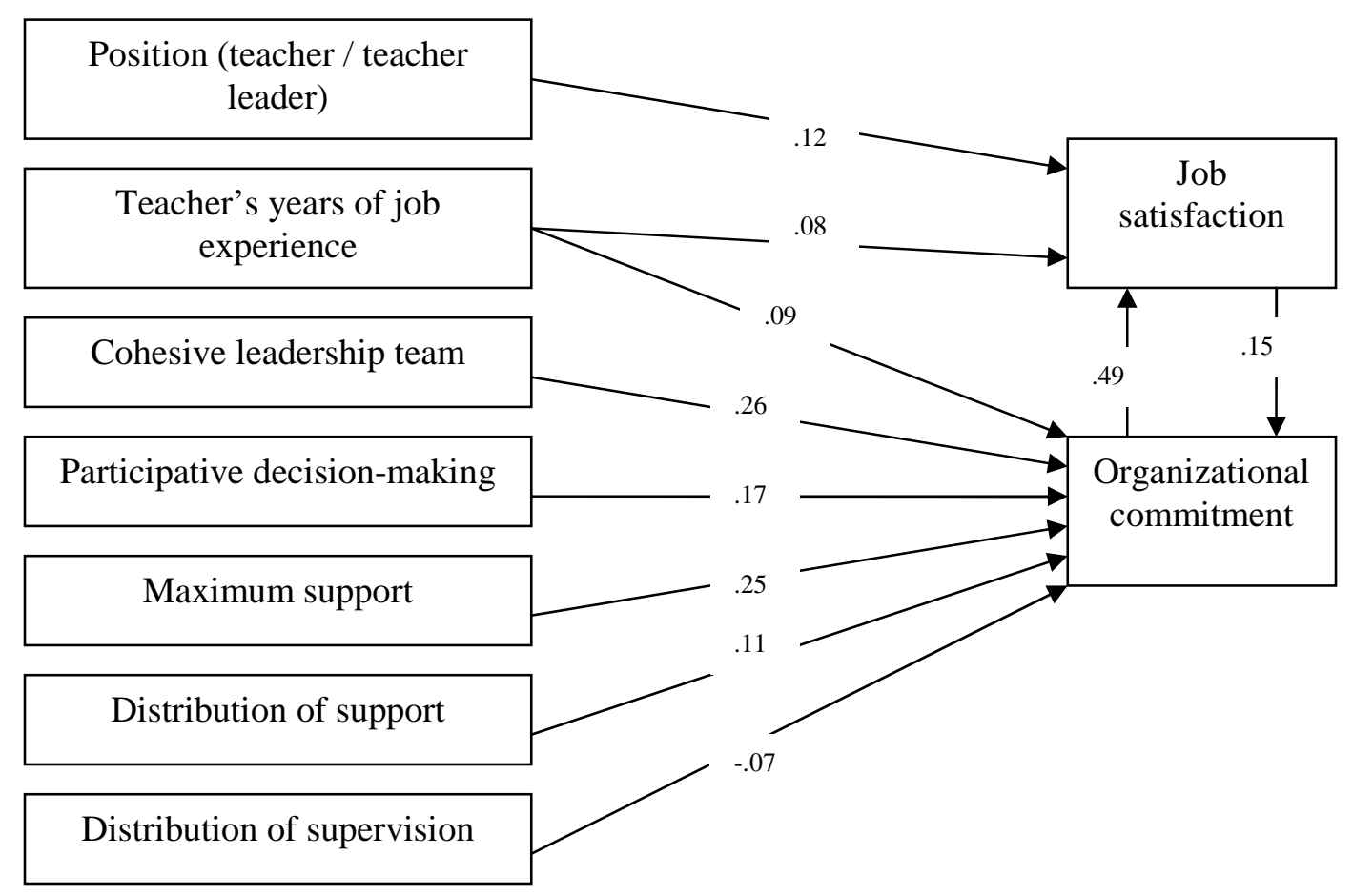

Figure 2. Modified research model and overview of standardized direct relations between the independent variables, and organizational commitment and job satisfaction. 


\section{Tables}

Table 1. Sample description.

\begin{tabular}{lccc}
\hline & $\begin{array}{c}\text { Teacher leader } \\
(\mathrm{n}=248)\end{array}$ & $\begin{array}{c}\text { Teachers } \\
(\mathrm{n}=1522)\end{array}$ & $\begin{array}{c}\text { Total } \\
(\mathrm{n}=1770)\end{array}$ \\
\hline Gender in \% & & & \\
Male & $53.3 \%$ & $41.9 \%$ & $43.5 \%$ \\
Female & $46.7 \%$ & $58.1 \%$ & $56.5 \%$ \\
\hline Age & & & \\
Mean & 46 & 39 & 40 \\
Minimum & 26 & 22 & 22 \\
Maximum & 62 & 65 & 65 \\
\hline Years of experience & & & \\
Mean & 8.9 & 13.7 & 13 \\
Minimum & 0.1 & 0.1 & 0.1 \\
Maximum & 39 & 40 & 40 \\
\hline
\end{tabular}


Table 2. Means and standard deviations of teachers' and teacher leaders' scores for the study variables.

\begin{tabular}{llccc}
\hline & & \multicolumn{3}{c}{ Mean (standard deviation) } \\
\hline & & $\begin{array}{c}\text { Teacher leader } \\
(\mathrm{n}=248)\end{array}$ & $\begin{array}{c}\text { Teachers } \\
(\mathrm{n}=1522)\end{array}$ & $\begin{array}{c}\text { Total } \\
(\mathrm{n}=1770)\end{array}$ \\
\hline \multirow{5}{*}{ Support } & $2.84(\mathrm{sd}=0.76)$ & $2.58(\mathrm{sd}=0.87)$ & $2.62(\mathrm{sd}=0.86)$ \\
& Principal & $2.65(\mathrm{sd}=0.79)$ & $2.45(\mathrm{sd}=0.87)$ & $2.48(\mathrm{sd}=0.86)$ \\
& Assistant principal & $2.63(\mathrm{sd}=0.67)$ & $2.27(\mathrm{sd}=0.86)$ & $2.32(\mathrm{sd}=0.85)$ \\
& Teacher leader & $3.15(\mathrm{sd}=0.53)$ & $2.92(\mathrm{sd}=0.67)$ & $2.95(\mathrm{sd}=0.66)$ \\
& Maximum support & $5.31(\mathrm{sd}=0.68)$ & $5.10(\mathrm{sd}=0.76)$ & $5.13(\mathrm{sd}=0.75)$ \\
\hline & Distribution of support & $2.29(\mathrm{sd}=0.98)$ & $2.62(\mathrm{sd}=1.07)$ & $2.66(\mathrm{sd}=1.06)$ \\
\multirow{5}{*}{ Supervision } & Teacher leader & $2.28(\mathrm{sd}=1.22)$ & $2.14(\mathrm{sd}=1.14)$ & $2.16(\mathrm{sd}=1.15)$ \\
& Asincipal & $1.33(\mathrm{sd}=1.14)$ & $1.41(\mathrm{sd}=1.08)$ & $1.40(\mathrm{sd}=1.09)$ \\
& Maximum supervision & $3.06(\mathrm{sd}=0.87)$ & $2.88(\mathrm{sd}=0.90)$ & $2.90(\mathrm{sd}=0.90)$ \\
& Distribution of supervision & $4.31(\mathrm{sd}=1.16)$ & $4.33(\mathrm{sd}=1.18)$ & $4.33(\mathrm{sd}=1.17)$ \\
\hline Cohesive leadership team & $2.89(\mathrm{sd}=0.59)$ & $2.68(\mathrm{sd}=0.66)$ & $2.71(\mathrm{sd}=0.65)$ \\
Participative decision-making & $2.62(\mathrm{sd}=0.57)$ & $2.44(\mathrm{sd}=0.66)$ & $2.47(\mathrm{sd}=0.65)$ \\
\hline Job satisfaction & $3.00(\mathrm{sd}=0.59)$ & $3.09(\mathrm{sd}=0.65)$ & $3.07(\mathrm{sd}=0.64)$ \\
Organizational commitment & $3.22(\mathrm{sd}=0.53)$ & $2.96(\mathrm{sd}=0.71)$ & $3.00(\mathrm{sd}=0.69)$ \\
\hline
\end{tabular}


Table 3. Multiple regression analysis.

\begin{tabular}{|c|c|c|c|c|c|c|c|c|c|c|c|c|c|c|c|}
\hline \multirow[b]{2}{*}{ Model } & \multirow[b]{2}{*}{ Variable } & \multicolumn{7}{|c|}{ A. Organizational commitment } & \multicolumn{7}{|c|}{ B. Job satisfaction } \\
\hline & & B & SE B & $\beta$ & $\begin{array}{l}\text { Adjusted } \\
\mathrm{R}^{2}\end{array}$ & $\begin{array}{l}\text { Adjusted } \\
\mathrm{R}^{2} \\
\text { Change }\end{array}$ & $\mathrm{df}$ & $\mathrm{F}$ & B & SE B & $\beta$ & $\begin{array}{l}\text { Adjusted } \\
\mathrm{R}^{2}\end{array}$ & $\begin{array}{l}\text { Adjusted } \\
\mathrm{R}^{2} \\
\text { Change }\end{array}$ & $\mathrm{df}$ & \\
\hline \multirow[t]{2}{*}{ demographic } & $\begin{array}{l}\text { Position } \\
\text { (teacher / teacher } \\
\text { leader }\end{array}$ & -.038 & .036 & -.019 & .044 & .044 & 2 & $\begin{array}{l}40.56 \\
* * *\end{array}$ & .208 & .043 & $.114 * * *$ & .028 & .028 & 2 & $\begin{array}{r}25 \\
*:\end{array}$ \\
\hline & $\begin{array}{l}\text { Teacher's years of } \\
\text { job experience }\end{array}$ & -.007 & .001 & $\begin{array}{c}- \\
.103^{* * *}\end{array}$ & & & & & -.008 & .001 & $-.134 * * *$ & & & & \\
\hline \multirow[t]{3}{*}{ + school } & School size & .000 & .000 & -.035 & .056 & .012 & 5 & $\begin{array}{c}21.31 \\
* * *\end{array}$ & .000 & .000 & -.046 & .033 & .005 & 5 & 12 \\
\hline & $\begin{array}{l}\text { Number leadership } \\
\text { team }\end{array}$ & -.003 & .004 & -.021 & & & & & -.001 & .004 & -.008 & & & & \\
\hline & $\begin{array}{l}\text { Principal's years of } \\
\text { job experience }\end{array}$ & .004 & .002 & .033 & & & & & .005 & .002 & $.048^{*}$ & & & & \\
\hline \multirow[t]{6}{*}{ + leadership } & $\begin{array}{l}\text { Cohesive leadership } \\
\text { team }\end{array}$ & .294 & .029 & $.277 * * *$ & .470 & .414 & 11 & $\begin{array}{c}138.39 \\
* * *\end{array}$ & .118 & .034 & $.120 * * *$ & .117 & .084 & 11 & 21 \\
\hline & $\begin{array}{l}\text { Participative } \\
\text { decision-making }\end{array}$ & .187 & .027 & $.175^{* * *}$ & & & & & .030 & .032 & .030 & & & & \\
\hline & Maximum support & .309 & .026 & $.295^{* * *}$ & & & & & .177 & .032 & $.181 * * *$ & & & & \\
\hline & $\begin{array}{l}\text { Maximum } \\
\text { supervision }\end{array}$ & -.030 & .017 & -.039 & & & & & -.016 & .021 & -.023 & & & & \\
\hline & $\begin{array}{l}\text { Distribution of } \\
\text { Support }\end{array}$ & .113 & .021 & $.124 * * *$ & & & & & .067 & .025 & $.078^{* *}$ & & & & \\
\hline & $\begin{array}{l}\text { Distribution of } \\
\text { Supervision }\end{array}$ & -.041 & .012 & $\begin{array}{c}- \\
.070^{* * *}\end{array}$ & & & & & -.028 & .015 & -.051 & & & & \\
\hline
\end{tabular}


Table 4. Overview of the standardized total, direct and indirect relations between the independent variables, and organizational commitment and job satisfaction and fit indices.

\begin{tabular}{|c|c|c|c|c|c|c|}
\hline & \multicolumn{2}{|c|}{ Standardized total effects } & \multicolumn{2}{|c|}{ Standardized direct effects } & \multicolumn{2}{|c|}{ Standardized indirect effects } \\
\hline & $\begin{array}{c}\text { Organizational } \\
\text { commitment }\end{array}$ & $\begin{array}{c}\text { Job } \\
\text { satisfaction }\end{array}$ & $\begin{array}{c}\text { Organizational } \\
\text { commitment }\end{array}$ & $\begin{array}{c}\text { Job } \\
\text { satisfaction } \\
\end{array}$ & $\begin{array}{c}\text { Organizational } \\
\text { commitment }\end{array}$ & $\begin{array}{c}\text { Job } \\
\text { satisfaction }\end{array}$ \\
\hline $\begin{array}{l}\text { Position (teacher } \\
\text { / teacher leader) }\end{array}$ & .018 & .129 & - & .121 & .018 & .008 \\
\hline $\begin{array}{l}\text { Teacher's years } \\
\text { of job experience }\end{array}$ & -.107 & -.132 & -.088 & -.083 & -.018 & -.049 \\
\hline $\begin{array}{l}\text { Maximum } \\
\text { support }\end{array}$ & .272 & .125 & .254 & - & .017 & .125 \\
\hline $\begin{array}{l}\text { Distribution of } \\
\text { support }\end{array}$ & .116 & .054 & .109 & - & .007 & .054 \\
\hline $\begin{array}{l}\text { Distribution of } \\
\text { supervision }\end{array}$ & -.075 & -.035 & -.070 & - & -.005 & -.035 \\
\hline $\begin{array}{l}\text { Cohesive } \\
\text { leadership team }\end{array}$ & .276 & .127 & .258 & - & .018 & .127 \\
\hline $\begin{array}{l}\text { Participative } \\
\text { decision-making }\end{array}$ & .185 & .085 & .173 & - & .012 & .085 \\
\hline $\begin{array}{l}\text { Organizational } \\
\text { commitment }\end{array}$ & .068 & .493 & - & .461 & .068 & .032 \\
\hline Job satisfaction & .148 & .068 & .139 & - & .010 & .068 \\
\hline $\mathrm{R}^{2}$ & .55 & .33 & & & & \\
\hline $\begin{array}{l}\chi^{2}(d f) \\
\text { Fit indices }\end{array}$ & & $\mathrm{CFI}=.998$ & $\begin{array}{r}16.9(d) \\
T L I=.989 ; \mathrm{SRN}\end{array}$ & $\begin{array}{l}=7) \\
\mathrm{R}=.013 ; \mathrm{R}\end{array}$ & $\mathrm{SEA}=.029$ & \\
\hline
\end{tabular}

